\title{
Thermodynamic analysis of an ice slurry thermal energy storage system for decreased size and cost of HVAC systems
}

\author{
Düşük boyutlu ve düşük maliyetli iklimlendirme sistemleri için bir buz \\ bulamacı ısıl enerji depolama sisteminin termodinamik analizi
}

\author{
Hasan ÖZCAN ${ }^{1 *}$ iD
}

${ }^{1}$ Mechanical Engineering Department, Engineering Faculty, Karabuk University, Karabuk, Turkey.

hasanozcan@karabuk.edu.tr

Received/Geliș Tarihi: 25.10.2016, Accepted/Kabul Tarihi: 17.04.2017

doi: $10.5505 /$ pajes.2017.32757

* Corresponding author/Yazıșllan Yazar Research Article/Araștırma Makalesi

\begin{abstract}
Performance assessment of a cold thermal energy storage (ITES - Ice Thermal Energy Storage) system with ice slurry generation for closed space air conditioning purposes is conducted. A detailed energy and exergy analysis are performed for the baseline system and some parametric studies are also presented for varying environmental conditions. Exergy definition is linked to sustainability and reported with graphical representations. A compressor \& condenser unit linked to an ice slurry generator and generated ice is stored at storage tank for specific hours of a day. Stored energy is then discharged to the building through a flat-plate heat exchanger. Thermodynamic analysis results suggest that high capacity cooling can be conducted with low capacity vapor compression refrigeration systems (VCR) by integrating ITES systems, leading to a significantly lower size and lower cost HVAC systems.
\end{abstract}

Keywords: Thermal energy storage, HVAC, Energy, Exergy
Öz

Bu çalıșmada kapalı alanların iklimlendirilmesi için buz bulamaçı (ice slurry) üretimi yapan bir buz depolama (ITES-Ice Thermal Energy Storage) sisteminin performans değerlendirmesi yapılmıștır. Temel alınan model için detaylı bir enerji ve ekserji analizi yapılmıș, değișen çevre ve sistem koşulları için parametrik çalışmalar rapor edilmiştir. Ekserji konsepti aynı zamanda sürdürülebilirlik ile bağıntılanarak grafiksel olarak sunulmuștur. Bir kompresör-kondenser ünitesi buz bulamaç üreteçine entegre edilmiş ve üretilen buz-glikol bulamaçı günün belirli saatlerinde depolanmıștır. Depolanan enerji daha sonra kapalı alana bir düz-plaka ısı değiştiricisi yardımıyla deşarje edilmektedir. Termodinamik analiz sonuçları, ITES yardımıyla düsük kapasiteli buhar sıkıştırmalı soğutma sistemleri ile yüksek kapasiteli soğutma yapılabileceğini göstermektedir ve bu entegrasyon düșük boyutlu ve düşük maliyetli iklimlendirme sistem kurulumuna öncülük etmektedir

Anahtar kelimeler: : Isıl enerji depolama, İklimlendirme, Enerji, Ekserji

cost of such integration is reported. The cooling unit of a department store is replaced by an ice storage system to increase the cooling [6]. Cost aspects of ITES (Ice thermal Energy Storage) are discussed in [7] for a Saudi Arabian case, in which integration of such technology is unattractive for flat electricity cost rates, while it is of importance to install ITES technologies when the electricity prices are variable, as expected. A feasibility study for a pre-cooling and TES adapted high school building is conducted in [8], resulting in around $47 \%$ annual savings. A difference between the ITES and CTES can be explained with the storage medium. When there is ice in the storage medium, these systems are called as ITES, and called CTES when there is no ice storage, however, the reason for storage is cooling.

This study focuses on the efficiency aspect of an ITES system using a glycol-water solution as the thermal energy storage carrier. Various parameters are taken into consideration for enhanced plant performance and sustainability. An ice slurry generator is adapted with storage for use as the cooling medium at busy hours, while decreasing the size of the HVAC system, significantly.

\section{System description}

In the system, the compressor \& condenser unit is linked to an ice slurry generator and generated ice is stored at a storage tank for specific hours of a day. Stored energy is then discharged to the building through a flat-plate heat exchanger.
An ice thermal energy storage (ITES) is introduced to an HVAC of large office building integrated with heat recovery and cold air distribution in [5], where projected savings and expected 
The considered system is illustrated in Figure 1 with state points and all system components. Vapor compression refrigeration unit (VCR) uses R22 as a working fluid between $40 /-12{ }^{\circ} \mathrm{C}$ condensing and evaporating temperatures. Energetic COP of the VCR unit is taken to be 2.4 for the baseline model. Evaporator of VCR unit takes the heat of glycol-water mixture and ice slurries are generated. Generated ice is then pumped using a glycol-water pump to the storage tank. Stored ice is then used to cool the air in flat-plate heat exchanger [9]. Following assumptions are made for the VCR system:

- 1-2: Isentropic compression,

- 2-3: Isobaric condensation,

- 3-4: Isenthalpic expansion,

- 4-1: Isobaric evaporation.

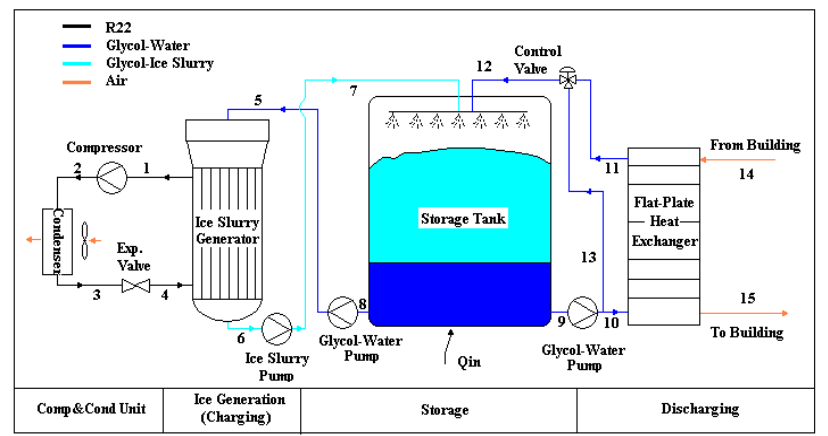

Figure 1: System schematic (Adapted from [9]).

\section{Analysis and assessment}

Since the main target of the study is to perform a thermodynamic assessment for the studied system, many assumptions are made in order to keep the variable system parameters as low as possible resulting in a decreased error through the analysis. Below assumptions are made for the analysis:

- All kinetic and potential effects are neglected,

- All pressure drops during piping is neglected,

- Specific heats of ice, water and glycol does not change by temperature variation,

- Work inputs for pumps and ice slurry generator are assumed to be far too lower than the compressor work, therefore only input to the overall system is assumed to be compressor work,

- $\quad$ VCR system works between $40 /-12{ }^{\circ} \mathrm{C}$ condensation and evaporation temperatures,

- $\quad$ COP of the system is taken to be 2.4 for the baseline model,

- $\quad$ Other assumed input values required for the system are shown in Table 1.

Cooling capacity profile and obtained data for the building for 24 hour of a day is represented in Figure 2. Charging process is performed during the off-peak hours and additional 2 hours of storage is conducted. Discharging is conducted on the peak hours from 9 am to $18 \mathrm{pm}$ to help decrease the overloads and oversizing of the refrigeration system. This selection decreases the investment cost of the system as well.
Table 1: Property data and range of variation.

\begin{tabular}{lcc}
\hline \multicolumn{1}{c}{ Property } & Unit & Range \\
\hline Dead state temperature $\left(T_{0}\right)$ & $\mathrm{K}$ & $293-313$ \\
Dead State Pressure $\left(P_{0}\right)$ & $\mathrm{kPa}$ & 101 \\
Storage temperature $\left(T_{s t}\right)$ & $\mathrm{K}$ & 262 \\
Coefficient of Performance $(C O P)$ & - & $2.0-3.0$ \\
Evaporator Temperature $\left(T_{c h}\right)$ & $\mathrm{K}$ & $260-265$ \\
Discharge Temperature $\left(T_{d i s}\right)$ & $\mathrm{K}$ & $271-275$ \\
Storage Tank Thermal resistance $\left(R_{T}\right)$ & $\mathrm{m}^{2} \mathrm{~K} / \mathrm{W}$ & 1.98 \\
Latent fusion of water $(L)$ & $\mathrm{kJ} / \mathrm{kg}$ & 334 \\
Specific heat of water $\left(C_{w}\right)$ & $\mathrm{J} / \mathrm{kg}^{\circ} \mathrm{C}$ & 4200 \\
Specific heat of ice $\left(C_{i c e}\right)$ & $\mathrm{J} / \mathrm{kg}^{\circ} \mathrm{C}$ & 2106 \\
Specific heat of glycol solution $\left(C_{g}\right)($ for & $\mathrm{J} / \mathrm{kg}^{\circ} \mathrm{C}$ & 3574 \\
30\% concentration) & & \\
Desired building temperature $\left(T_{b}\right)$ & $\mathrm{K}$ & 293 \\
Storage area $(A)$ & $\mathrm{m}^{2}$ & 150 \\
\hline
\end{tabular}

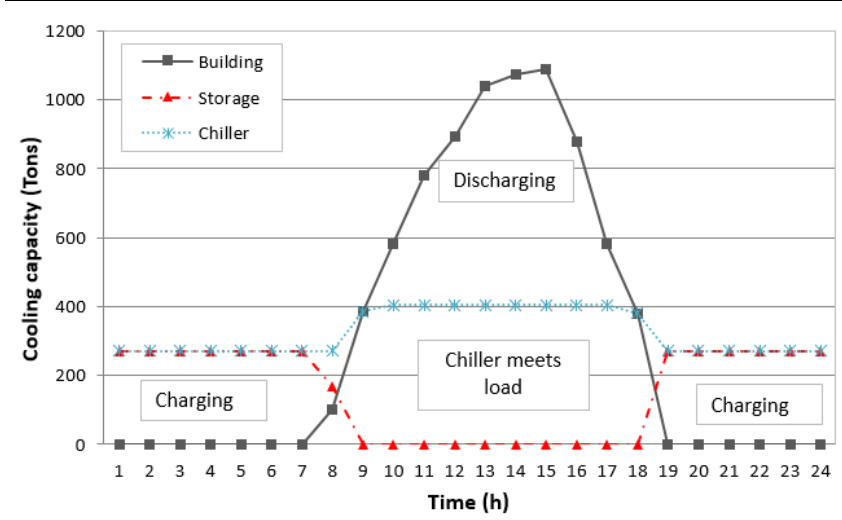

Figure 2: Cooling capacity profile for the building under consideration (partial storage).

Thermodynamic analysis of the system is based on simplified steady-state modeling of all components through mass, energy, entropy, and exergy balances as follows [10]:

$$
\begin{gathered}
\sum \dot{m}_{i}-\sum \dot{m}_{o}=\Delta m_{\text {sys }} \\
\dot{\mathrm{E}}_{\text {in }}-\dot{\mathrm{E}}_{\text {out }}=\Delta \mathrm{E}_{\text {sys }} \\
\dot{\mathrm{Ex}}_{\mathrm{in}}-\dot{\mathrm{Ex}}_{\text {out }}-\dot{\mathrm{Ex}} \mathrm{des}_{\mathrm{des}}-\dot{\mathrm{Ex}}=\Delta \mathrm{Ex}_{\text {sys }} \\
\dot{S}_{\text {in }}-\dot{S}_{\text {out }}+\sum\left(\dot{Q}_{r} / T_{r}\right)+\dot{S}_{\text {gen }}=\Delta S_{\text {sys }}
\end{gathered}
$$

Here, the definition $E x$ refers to exergy rate and calculated with its specific form as follows:

$$
\dot{\mathrm{Ex}}=\dot{\mathrm{m}} \cdot \mathrm{ex}
$$

And the specific exergy is the sum of chemical and physical exergy of a substance which are also defined in the flowing equations below, as follows:

$$
\begin{gathered}
\mathrm{ex}=\mathrm{ex}_{\mathrm{ph}}+\mathrm{ex}_{\mathrm{ch}} \\
\mathrm{ex}_{\mathrm{ph}}=\left(\mathrm{h}-\mathrm{h}_{\mathrm{o}}\right)-\mathrm{T}_{0} \cdot\left(\mathrm{s}-\mathrm{s}_{\mathrm{o}}\right) \\
e x_{c h}=\sum x_{i} \overline{e x}_{c h}{ }^{0}-R T_{0} \cdot \sum x_{i} \ln \left(x_{i}\right)
\end{gathered}
$$

The third and fourth components of Eq. (3) refer to exergy destruction and thermal exergy rates as follows:

$$
\dot{E x} Q=\dot{Q} \cdot\left(1-\frac{T_{L}}{T_{H}}\right)
$$




$$
\dot{E} x_{\text {des }}=\dot{I}=T_{0} \cdot \dot{S}_{g e n}
$$

COP of the refrigeration cycle is simply the ratio of heat addition to the evaporator from the glycol-water mixture, and for the exergetic COP, the nominator changes into thermal exergy of added heat while the compressor power remains the same. All components throughout the studied system are individually analyzed using the balance equations given in Eqs. 1 to 4. Given assessment above is for steady state modeling of components. Since air is also used in the system, following definition is used to calculate the entropy change in an ideal gas:

$$
\Delta \mathrm{s}=\mathrm{c}_{\mathrm{avg}} \ln \left(\frac{\mathrm{T}_{\mathrm{f}}}{\mathrm{T}_{\mathrm{i}}}\right)
$$

Where, $\mathrm{c}_{\mathrm{avg}}$ is the average specific heat of ideal gas. There is also a phase change process from water to ice and vice versa, in which the entropy change is defined as follows [4]:

$$
\Delta s=c_{\text {ice }} \ln \left(\frac{T_{i}}{T_{f}}\right)+\frac{L}{T_{\text {freeze }}}+c_{w} \ln \left(\frac{T_{i}}{T_{f}}\right)
$$

Where $L$ is the latent fusion of water. Here charging, storage and discharging processes are required to be modeled in a transient manner. Modeling of the overall process needs to be treated non-steadily by considering charging, storage, and discharging processes individually. For the charging process, the energy and entropy balances can be written as follows [4]:

$$
\begin{gathered}
\mathrm{m}_{\mathrm{g}-\mathrm{w}}\left(\mathrm{h}_{8}-\mathrm{h}_{7}\right)=\mathrm{m}\left(\frac{\mathrm{du}}{\mathrm{dt}}\right)+\frac{\mathrm{dQ}}{\mathrm{dt}} \\
m_{7} h_{7}+\frac{m_{i} s_{i}}{\Delta t}+\frac{S_{g e n}}{\Delta t}=m_{f} s_{f}+m_{8} h_{8}+\frac{Q}{\Delta T}
\end{gathered}
$$

The energy input to the storage tank during storage phase is calculated using the following definition [4]:

$$
\mathrm{Q}_{\mathrm{in}, \mathrm{st}}=\frac{\mathrm{A}_{\mathrm{st}}\left(\mathrm{T}_{0}-\mathrm{T}_{\mathrm{st}}\right)}{\mathrm{R}_{\mathrm{t}}} \Delta \mathrm{t}
$$

Where $R_{t}$ and $A_{\text {st }}$ are storage tank thermal resistance and storage area as given in Table 1 . The irreversibility occurring through storage is [4]:

$$
\mathrm{I}=\mathrm{m}_{\mathrm{w}} \mathrm{c}_{\mathrm{ice}} \mathrm{T}_{0} \ln \left(\frac{\mathrm{T}_{\mathrm{st}}+\Delta \mathrm{T}}{\mathrm{T}_{\mathrm{st}}}\right)
$$

For the discharging process as given in the schematics, following definitions are used to balance the energy and entropy components of this process as follows [4]:

$$
\begin{gathered}
m_{9} h_{9}+\frac{m_{i} u_{i}}{\Delta t}=m_{12} h_{12}+\frac{m_{f} u_{f}}{\Delta t} \\
m_{9} h_{9}+\frac{m_{i} s_{i}}{\Delta t}+\frac{S_{g e n}}{\Delta t}=m_{12} s_{12}+\frac{m_{f} s_{f}}{\Delta t}
\end{gathered}
$$

Total energy and exergy efficiencies of the Thermal energy storage is calculated as multiplication od efficiencies of charging, storage, and discharging process by the following definitions [1]:

$$
\eta_{\text {TES }}=\prod_{j=1}^{3} \eta_{j}
$$

$$
\psi_{\mathrm{TES}}=\prod_{\mathrm{j}=1}^{3} \psi_{\mathrm{j}}
$$

Energy and exergy efficiencies of all three processes $(j=1,2,3)$, correspond to charging, storage, and discharging, respectively, as given below [1]:

$$
\begin{array}{cc}
\eta_{\mathrm{ch}}=\frac{\mathrm{m} \Delta \mathrm{u}}{\mathrm{E}_{\mathrm{in}}}, & \Psi_{\mathrm{ch}}=\frac{\mathrm{m} \Delta \mathrm{x}_{\mathrm{f}-\mathrm{i}}}{\mathrm{Ex}_{8}-\mathrm{Ex}_{7}} \\
\eta_{\mathrm{st}}=1-\frac{\mathrm{Q}_{\mathrm{in}, \mathrm{st}}}{\Delta \mathrm{E}_{\mathrm{ch}}}, & \Psi_{\mathrm{st}}=\frac{1-\left(\mathrm{ex}^{\mathrm{Q}}+\mathrm{I}\right)}{\Delta \mathrm{ex}_{\mathrm{ch}}} \\
\eta_{\mathrm{dis}}=\frac{\mathrm{H}_{12}-\mathrm{H}_{9}}{\Delta \mathrm{E}_{\mathrm{dis}}}, & \psi_{\mathrm{dis}}=\frac{\mathrm{ex}_{7}-\mathrm{ex}_{5}}{\Delta \mathrm{ex}_{\mathrm{dis}}}
\end{array}
$$

Finally, overall system energy and exergy efficiencies can be written by considering as the ratio main useful output to the required inputs of energy and exergy contents as follows [1]:

$$
\begin{gathered}
\eta_{\mathrm{ov}}=\frac{E_{14}-E_{15}}{W_{\text {comp }}} \\
\psi_{\text {ov }}=\frac{E_{14}-E x_{15}}{W_{\text {comp }}}
\end{gathered}
$$

And the sustainability index, which is a connection between the thermodynamic performance of thermal systems with the environmental impacts, is ultimately dependent on the exergy efficiency as follows [1]:

$$
\mathrm{SI}=\frac{1}{1-\psi_{\mathrm{ov}}}
$$

Given basic thermodynamic model is applied for the system and corresponding results are discussed in detail.

\section{Results and discussion}

Discussion of results and variations of key parameters with the environmental and system parameters are performed in this section. Energy and exergy efficiencies for the baseline model are represented in Figure 3. Energy efficiencies of charging, discharging and storage processes are more than 98\%, however, exergy efficiencies of charging and discharging is lower due to losses and irreversibilities by time. For a $150 \mathrm{~m}^{2}$ of storage area, the size of the system is significantly high, which can be used for medium- to large-size buildings.

Exergy efficiency of charging, discharging, storage and overall ITES are $64 \%, 98 \%, 17 \%$ and $10.6 \%$, respectively. Irreversibility ratio of each sub unit to overall irreversibility and amounts of irreversibilities are illustrated in Figure 4. Discharging process shows the highest irreversibility ratio and the corresponding irreversibility value due to its relatively higher temperature interaction. $55.7 \%$ of total ITES unit irreversibility belongs to discharging, while $43.6 \%$ belongs to charging process. Here, storage irreversibility is significantly lower than those of charging and discharging at $0.7 \%$. The main reason of low irreversibility value is the time dependence of the evaluated irreversibility and a short period of storage-only process is considered. 


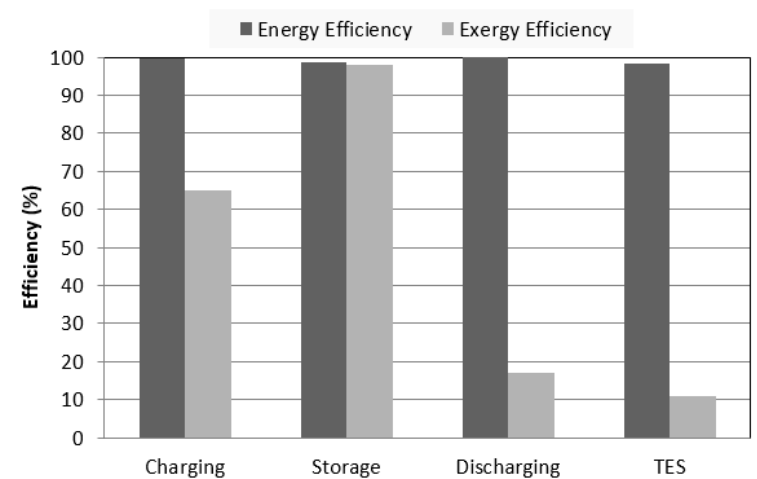

Figure 3: Energy and exergy efficiencies for the baseline model.

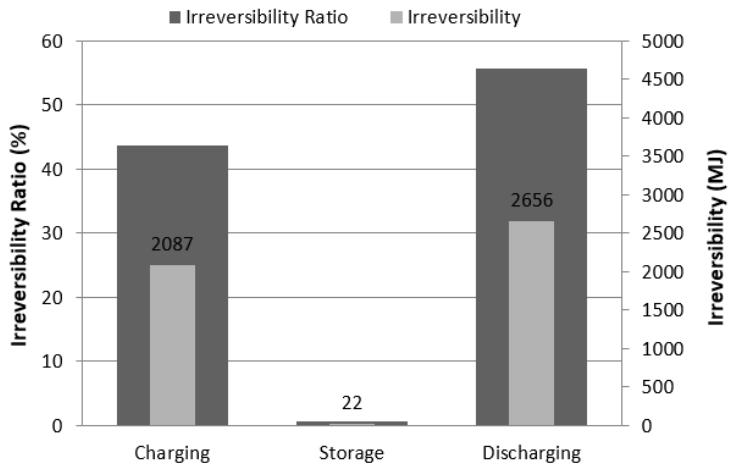

Figure 4: Irrevesibility ratio and irrevesibilities for charging, storage and discharging process.

COP of the VCR unit is taken to be 2.4 for the baseline model. A system with better COP decreases the power consumption and increases the exergetic COP of the VCR system. Figure 5 illustrates the effect of COP on power consumption and exergetic COP. It is possible and convenient to generate a COP value from the studied VCR unit, however, since the main focus of the study is the overall time-dependent storage process, this assumption is made for analysis simplicity and the COP range at a reasonable span, showing consistency with industrial VCR applications. For the same amount of evaporator cooling load production, higher COP values result in lower power consumption by also significantly increasing the exergy based COP of the VCR system.

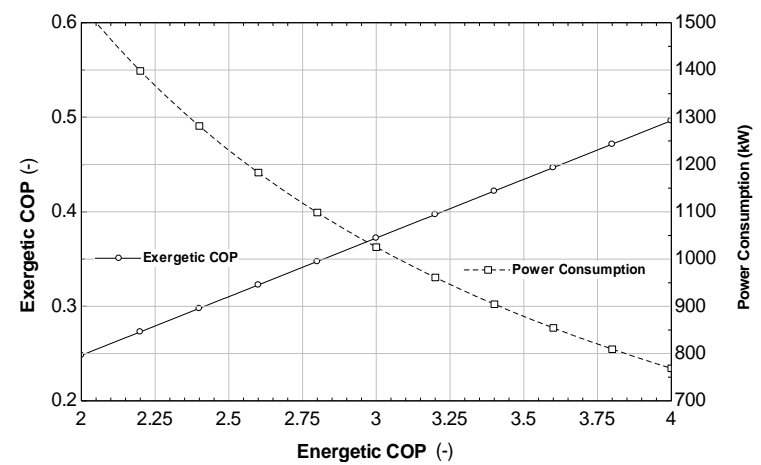

Figure 5: Variation of exergetic COP and power consumption via energetic COP.

Dead state temperature is an influential environmental parameter for evaluation of both energy and exergy efficiencies of all sub units and the overall ITES system since these system are in interaction with environmental conditions. Figure 6 and
7 represents the effect of dead state temperature on energy and exergy efficiencies, respectively. Increasing dead state temperature decreases energy efficiencies of the ITES system but it slightly increases the exergy efficiency of the ITES system. Heightened ambient temperature provides a better quality ice storage.

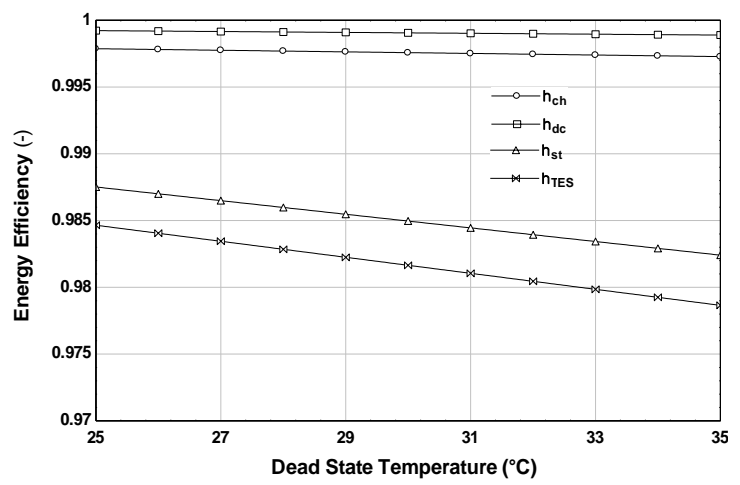

Figure 6: Ambient temperature effect on energy efficiencies of ITES sub-processes.

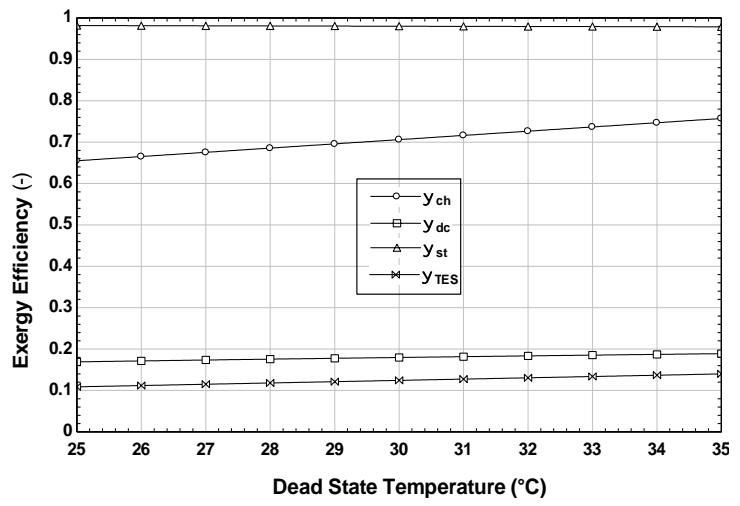

Figure 7: Ambient temperature effect on exergy efficiencies of TES sub processes.

Another way to understand the scope for improvement at the design stage as well as in the existing system is through the sustainability index (SI). Sustainability index is directly related to the exergy efficiency, thus sustainability should be considered together with exergy analysis. Figure 8 illustrates the variation of sustainability index and ITES exergy efficiency by dead state temperature. At higher ambient temperatures both the sustainability index and the overall exergy efficiency increase while the sustainability index shows a higher yield at higher ambient temperatures.

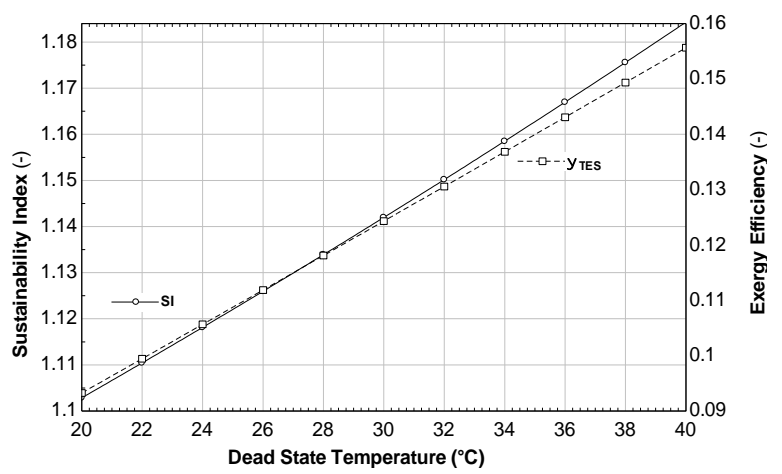

Figure 8: Ambient temperature effect on TES exergy efficiency and sustainability. 


\section{Conclusions}

A detailed thermodynamic performance analysis is performed for an ice slurry cold thermal energy storage system and performance parameters are illustrated with parametric studies. Following concluding remarks are extracted from the study:

- $\quad$ Largest irreversibility occurs in discharging process due to losses to environment by time and low efficient heat exchange. Environmental conditions and duration of the process strongly effects the system energy and exergy efficiencies,

- High performance refrigeration system selection decreases the power consumption of such system and increases efficiencies,

- Overall ITES energy and exergy efficiencies are determined to be $98.4 \%$, and $10.9 \%$, respectively,

- Cooling system electricity cost of large buildings can be decreased by installing ITES systems, since these systems are charged at off peak hours while the prices are lower, and especially adaptable in large malls.

- High capacity cooling can be conducted with lower capacity vapor compression refrigeration systems by integrating ITES systems, leading to less capital investment costs.

\section{Nomenclatature}

E : Energy (kJ),

Ex : Exergy(kJ),

$\mathrm{L} \quad$ : Latent heat $(\mathrm{kJ})$

$\mathrm{P}$ : Pressure $(\mathrm{kPa})$,

Q : Heat $(\mathrm{kJ})$

$\mathrm{S}$ : Entropy $(\mathrm{kJ} / \mathrm{K})$,

$\mathrm{T}$ : Temperature $(\mathrm{C}-\mathrm{K})$,

$\mathrm{x}$ : Concentration (-).

\section{Greek Letters}

$\eta \quad: \quad$ Energy efficiency (-),

$\psi$ : Exergy efficiency (-).

\section{Subscripts}

0 : Ambient,

b : Building,

ch : Chemical, Charging,

comp : Compressor,

dis : Discharge,

f : Final,

gen : Generation,

$\begin{array}{lll}\mathrm{H} & : & \text { High, } \\ \dot{\mathrm{I}} & : & \text { Initial, } \\ \mathrm{L} & : & \text { Low, } \\ \mathrm{Ov} & : & \text { Overall, } \\ \mathrm{Ph} & : & \text { Physical, } \\ \mathrm{St} & : & \text { Storage, } \\ \text { sys } & : & \text { Systems. }\end{array}$

\section{Superscripts}

Q : Heat.

\section{Acronyms}

$\begin{array}{lll}\text { COP } & : \text { Coefficient of performance, } \\ \text { CTES } & : \text { Cold thermal energy storage, } \\ \text { HVAC } & : \text { Heating, ventilation, air conditioning, } \\ \text { ITES } & : \text { Ice thermal energy storage, } \\ \text { SI } & : \text { Sustainability index, } \\ \text { TES } & : \text { Thermal energy storage, } \\ \text { VCR } & : \text { Vapor compression refrigeration. }\end{array}$

\section{References}

[1] Dincer I, Rosen M. Thermal Energy Storage: Systems and Applications. $1^{\text {st }}$ ed. West Sussex, England, John Wiley \& Sons, 2002.

[2] Rismanchi B, Saidur R, BoroumandJazi G, Ahmed S. "Energy, exergy and environmental analysis of cold thermal energy storage (CTES) systems". Renewable and Sustainable Energy Reviews, 16(8), 5741-5746, 2012.

[3] Saito A. "Recent advances in research on cold thermal energy storage". International Journal of Refrigeration, 25(2), 177-189, 2002.

[4] MacPhee D, Dincer I. "Performance assessment of some ice TES systems". International Journal of Thermal Sciences, 48(12), 2288-2299, 2009.

[5] Tackett RK. "Case study: office building uses ice storage, heat recovery, and cold air distribution". ASHRAE Transactions, 95, 1113-1121, 1989.

[6] Crane JM, Dunlop C. "Ice storage system for a department store". ASHRAE Journal, 36(1), 1994.

[7] Habeebullah BA. "Economic feasibility of thermal energy storage systems". Energy and Buildings, 39(3), 355-363, 2007.

[8] Morgan S, Krarti M. "Field testing of optimal controls of passive and active thermal storage". ASHRAE Transactions, 116(1), 2010.

[9] Kirby P, Nelson PE. "Ice slurry generator". 89th Annual Idea Conference, San Antonio, USA, 1998.

[10] Dincer I, Rosen MA. Exergy: Energy, Environment And Sustainable Development. $2^{\text {nd }}$ ed, London, Elsevier, 2012. 